DOI: https://doi.org/10.24127/ajpm.v10i1.3440

\title{
ANALYTICAL THINKING PROCESS OF STUDENTS IN SOLVING MATHEMATICAL PROBLEMS OF QUADRATIC FUNCTIONS
}

\author{
Naela Nur Azizah $^{1}$, Susiswo $^{2 *}$, Sisworo $^{3}$ \\ 1,2*3 Universitas Negeri Malang, Malang, Indonesia \\ ${ }^{*}$ Corresponding author. Jl. Semarang No. 5 Kota Malang, 65145, Jawa Timur, Indonesia \\ E-mail: $\quad$ naela.nur.1903118@students.um.ac.id ${ }^{1)}$ \\ susiswo.fmipa@um.ac.id ${ }^{2 *}$ \\ sisworo.fmipa@um.ac.id ${ }^{3)}$
}

Received 30 December 2020; Received in revised form 06 March 2021; Accepted 05 April 2021

\begin{abstract}
This study is set to describe students' analytical thinking processes in solving mathematical problems, especially in quadratic functions. It employs a qualitative approach with qualitative descriptive research. The subjects in this study are one student with high mathematics ability, one student with medium mathematics ability, and one student with low mathematics ability of Tenth Grade of State Islamic Senior High School 3 Tulungagung. Data collection are carried out through task-based interviews. Meanwhile, data analysis technique are data reduction, data presentation, and conclusion Based on the results of data analysis and discussion, it is concluded that (1) The student with high mathematical ability pass several stages, namely differentiating, and organizing, he/he can solve the quadratic function problem properly according to the problem solving steps. (2) The student with medium mathematical ability can go through differentiating and organizing stages. But at the attributing stage, he/she are less able to solve problems based on the objectives. (3) The student with low mathematical ability tends not to pass differentiating, organizing, and attributing analytical thinking stages. He/she are less able to solve quadratic function problems according to the solving steps.
\end{abstract}

Keywords: Analytical thinking process; problem solving; quadratic functions

\begin{abstract}
Abstrak
Penelitian ini bertujuan mendeskripsikan proses berpikir analitis siswa dalam pemecahan masalah matematika terutama pada materi fungsi kuadrat. Penelitian ini menggunakan pendekatan kualitatif dengan jenis penelitian deskriptif kualitatif. Subjek dalam penelitian ini adalah satu siswa berkemampuan matematika tinggi, satu siswa berkemampuan matematika sedang dan satu siswa berkemampuan matematika rendah kelas X Madrasah Aliyah Negeri 3 Tulungagung. Pengumpulan data dilakukan melalui wawancara berbasis tugas. Sedangkan teknik analisis data dalam penelitian ini meliputi tahap reduksi data, penyajian data dan penarikan kesimpulan Berdasarkan hasil analisis data dan pembahasan diperoleh simpulan bahwa (1) Siswa dengan kategori kemampuan matematika tinggi mampu melalui tahap berpikir analitis differentiating, organizing dan attributing dengan baik. Siswa dapat memecahkan masalah fungsi kuadrat dengan baik sesuai dengan langkah-langkah penyelesaian masalah. (2) Siswa dengan kategori kemampuan matematika sedang mampu melalui tahap berpikir analitis differentiating dan organizing, namun pada tahap attributing siswa kurang mampu menyelesaikan sesuai dengan tujuan dari permasalahan yang disajikan. (3) Siswa dengan kategori kemampuan matematika rendah memiliki kecenderungan tidak melakukan tahap berpikir analitis differentiating, organizing dan attributing. Siswa kurang mampu dalam memecahkan masalah fungsi kuadrat sesuai dengan langkah penyelesaian.
\end{abstract}

Kata Kunci: Fungsi kuadrat; pemecahan masalah; proses berpikir analitis 
DOI: https://doi.org/10.24127/ajpm.v10i1.3440

\section{INTRODUCTION}

Problem solving is an ability that must be mastered by the students in learning mathematics. The students can develop general skills in solving reallife problems and apply mathematics in real life situations by having problemsolving ability (Gurat, 2018). Several activities in solving mathematics problems can be in the form of solving story problems, solving non-routine problems, applying mathematics in everyday life or other situations, and proving or creating or testing conjectures (Sutiarso, 2017). Thus, problem solving is an important element in mathematics as a process of finding solutions to the presented problems.

The problem solving process requires thinking skills. One of the important thinking skills to be mastered by students is the ability to think analytically. This is because analytical thinking is a set of the same behaviors which involves elements of investigation and further situations with less well-defined results and parameters (Robbins, 2011). Sitthipon (2012) states that analytical thinking is the competence in identifying or classifying various aspects in the form of objects, stories or events, as well as the ability to find the relationship between these aspects. In line with that, analytical thinking means encouraging students to analyze, criticize, assess, compare, contrast, and evaluate (Chadwick, 2016). These six things are part of the problem solving process. Analytical thinking as part of the problem-solving process is considered significant to provide the skills needed to prepare children for more complex lives (Thaneerananon et al., 2016). As stated by Montaku (2011), analytical thinking skill will provide benefit for students because it is related to academic achievement. If the student's analytical thinking ability is high or good, the academic achievement that will be obtained is also high. Therefore, the research related to analytical thinking processes needs to be conducted.

One of the materials given at the Senior High School (MA) level is the quadratic function material. In existing researches, students experience difficulties in solving quadratic function problems. The test scores of students' mathematics learning outcomes in solving quadratic function questions ranged from 5 to 59 with an average of 25.9; median 21 and mode 14. Types of errors that students make in solving quadratic function questions include concept errors, principle errors, and calculation errors (Isfan et al., 2019). This is in line with (Rizki \& Wildaniati, 2015) which states that students experience confusion in applying the quadratic function formula to solving problems. Besides, that students do not understand the meaning of quadratic function problems and they are in a hurry to do the task (Ayunengdyah et al., 2020).

Researches related to analytical thinking in students conduct several times, but there is no research that focuses on analytical thinking processes in solving mathematical problems on the material of quadratic functions. In the last ten years, researches related to analytical thinking in various countries examine the characteristics of students' analytical thinking (Parta, 2016), the characteristic profile of analytical thinking (Qolfathiriyus et al., 2019a); (Ilma et al., 2017), and the development of learning management emphasizing analytical thinking (Sitthipon, 2012).

Based on some of the researches, it can be concluded that the average value of students' learning 
outcomes on the quadratic function material is low. This shows that students have low problem-solving abilities. Problem-solving skills are related to analytical thinking skills. In accordance with the opinion of (Qolfathiriyus et al., 2019b) who said that analytical thinking is very important to help students solve math problems. The existence of a math problem makes a person think of a solution so that analytical thinking appears. It means there is a relationship between analytical thinking and mathematical problem-solving. The relationship is that when a person performs a problem-solving process using formulas, concepts, properties, principles, theorems, and postulates, he performs a stage of analytical thinking. Because solving mathematical problems is influenced by students 'analytical abilities, it is necessary to carry out an in-depth analysis of the extent to which students' analytical thinking skills. The results of this analysis can be utilized as a basis for formulating solutions to improve analytical thinking skills and problem-solving. So that research related to analytical thinking in solving mathematical problems needs to be done. Based on this, this research is conducted to explore information and descriptions of the analytical thinking process carried out by students in solving math problems with the quadratic function material.

\section{METHOD}

This study seeks to reveal in depth the students' analytical thinking processes in solving mathematics problems analyzed based on written assignments and interviews. So, this is called as qualitative research. Prospective research subjects are 23 students of State Islamic Senior High School 3 Tulungagung. They are given the task of solving the quadratic function problem, then the results of the students' work are analyzed and grouped according to their mathematics abilities, so that the subjects in this study consist of three students (1 student with high mathematics ability, 1 student with medium mathematics ability, and 1 student with low mathematics ability). The classification of students into the three groups is in accordance with the report card scores and information from the mathematics subject teacher.

The main instrument in this research is the researcher himself. Supporting instruments used in this study are assignment sheets, interview guides, recording tools, and field notes. The assignment sheet consists of a quadratic function problem solving question designed to determine the analytical thinking process in solving mathematical problems. Based on the assignment sheet, as well as suggestions from the teacher, the selected subjects are interviewed to find out further analytical thinking processes. The results of the interview are then triangulated with the results of the previous problem-solving tests so that a description of the students' analytical thinking processes in solving math problems with the quadratic function material is obtained. The recording tool is used to record the process of assignments and interviews. Then the researchers use field notes to record the information.

Indicators of analytical thinking in this study can be seen in Table 1 (adapted from Anderson dkk., (2001). While the quadratic function assignment sheet can be seen in Figure 1 . 
DOI: https://doi.org/10.24127/ajpm.v10i1.3440

Table 1. Description of analytical thinking indicator in problem-solving

\begin{tabular}{|c|c|c|}
\hline $\begin{array}{c}\text { Stage of } \\
\text { Analytical } \\
\text { thinking }\end{array}$ & Description & Indicator \\
\hline Differentiating & $\begin{array}{l}\text { Differentiating is the ability } \\
\text { when students can sort } \\
\text { information into the } \\
\text { important information and } \\
\text { discard or ignore irrelevant } \\
\text { ones to achieve an interest or } \\
\text { find solutions to problems }\end{array}$ & $\begin{array}{l}\text { - The students analyze the presented } \\
\text { problems } \\
\text { - The students gather the necessary } \\
\text { information to solve the problem } \\
\text { - The students review alternative } \\
\text { solutions }\end{array}$ \\
\hline Organizing & $\begin{array}{l}\text { Organizing is an activity } \\
\text { when students begin to } \\
\text { organize and arrange } \\
\text { sections of information that } \\
\text { are sorted into certain groups } \\
\text { that have a suitability } \\
\text { between them so that they } \\
\text { can find the right solution }\end{array}$ & $\begin{array}{l}\text { - The Students organize the obtained } \\
\text { information to solve problems } \\
\text { - The Students describe solutions to } \\
\text { problems and strategies }\end{array}$ \\
\hline Attributing & $\begin{array}{l}\text { attributing occurs when } \\
\text { students can find the existing } \\
\text { patterns from a collection of } \\
\text { information, so that they can } \\
\text { ascertain the intention and } \\
\text { purpose of solving problems. }\end{array}$ & $\begin{array}{l}\text { - The Students relate problems that } \\
\text { are equipped with information or } \\
\text { knowledge to solve problems } \\
\text { - The students can rebuild new } \\
\text { schemes to solve problems } \\
\text { - The students can solve problems } \\
\text { according to the objectives of the } \\
\text { presented problems. }\end{array}$ \\
\hline
\end{tabular}

Pay attention to the following form!

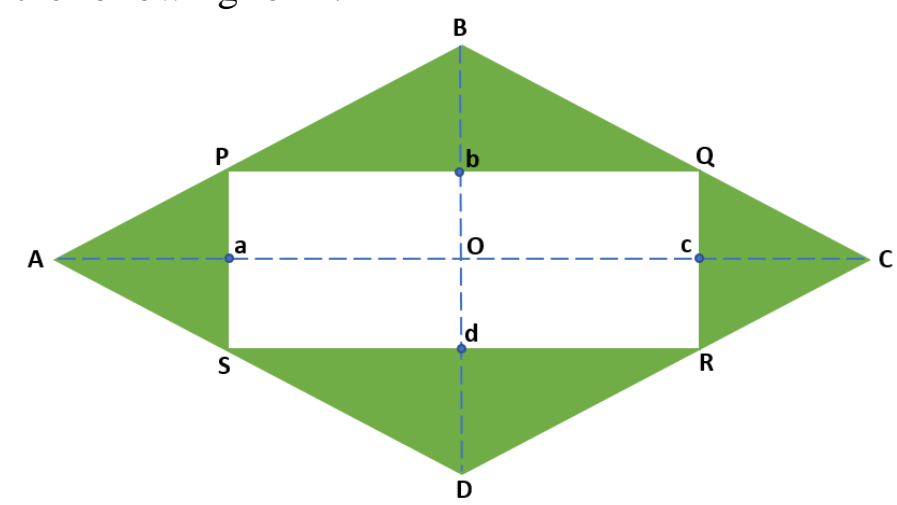

If $C O=A O=6 \mathrm{~cm}, D O=B O=4 \mathrm{~cm}$, Suppose $A a=C c=x$

If PQRS is a rectangle with vertices tangent to the side of the rhombus ABCD. Determine the minimum area of the shaded area!

Figure 1. Quadratic function taks. 
DOI: https://doi.org/10.24127/ajpm.v10i1.3440

Data analysis employs the Milles \& Huberman stages, namely data reduction, data presentation, and conclusion (Miles et al., 2014). Meanwhile, the procedures carried out in this study include three stages, namely the preparation stage, the implementation stage, and the completion stage.

\section{RESULT AND DISCUSSION}

Based on the research objectives, the data in this study are qualitative data in the form of descriptions of students' analytical thinking processes in solving math problems with the quadratic function material. Data descriptions are presented in written form as well as expressions from students selected as subjects. Before data collection is carried out, the preparatory stage is first carried out by compiling problemsolving problems to reveal the analytical thinking process in solving mathematical problems. Based on the given problems related to the quadratic function material, then the implementation stage is carried out, namely data collection. The subject answers in writing, then the subject is interviewed to explain transparently regarding the answers. Furthermore, 3 out of 23 students are selected as interview subjects (Subject 1 (S1), Subject 2 (S2), Subject 3 (S3). Referring to Figure $1 \mathrm{~A}$ description of the written data and verbal transcript of the three subjects is obtained as follows.

\section{Subject 1 (S1) has high mathematical thinking ability}

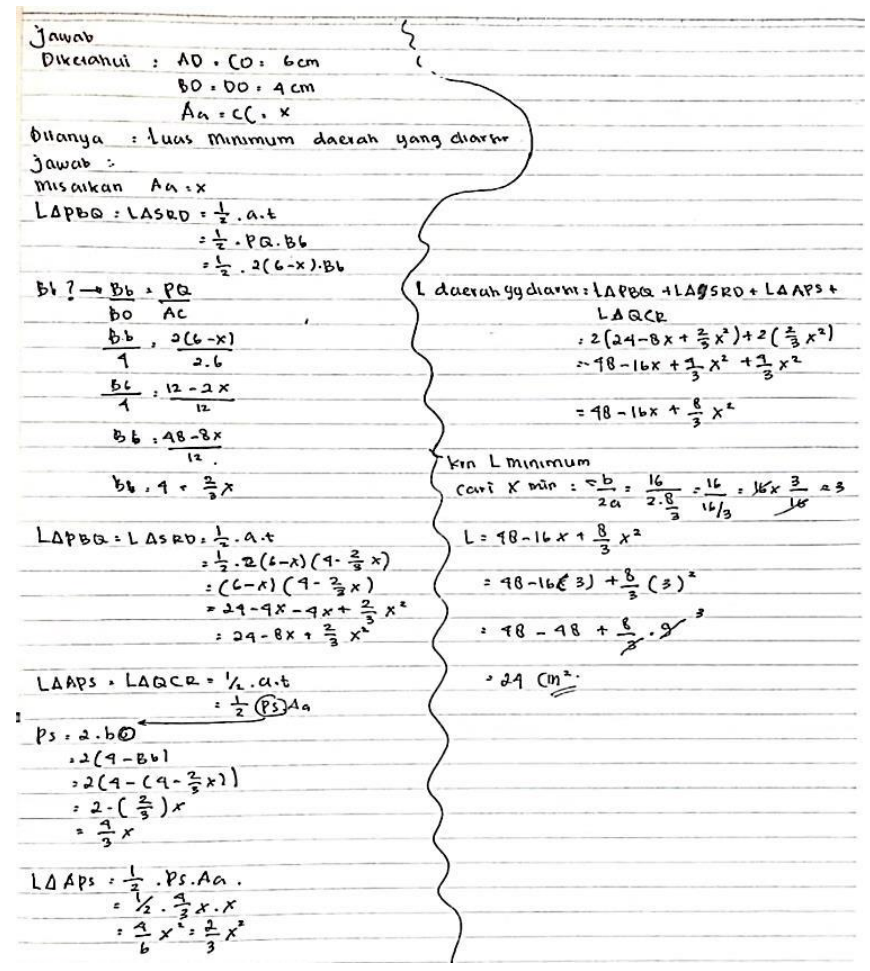

Figure 2. The answer of subject 1 (S1)

Based on Figure 2, it can be seen that S1 describes the presented problems and collects the information needed to solve the problem. S1 writes 
the known and the asked information in the questions. In this case, S1 conducts some differentiating stages in analytical thinking. To reveal the differentiating process in depth, the researchers conduct interviews with S1. Based on the results of the interview, S1 states that the known information in the questions is the diagonal length of $\mathrm{AO}=$ $\mathrm{OC}=6$, and $\mathrm{BO}=\mathrm{OD}=4 \mathrm{~cm}$, then taking the example of $\mathrm{Aa}=\mathrm{cC}=\mathrm{x}$, and the asked information is looking for the shaded area. Then S1 said that the mathematical concepts used are the area of the plane and the quadratic function. The results of the interviews reveal that S1 can sort and collect important information such as the known information and the asked in the questions. Then S1 can explore alternative solutions, namely by using the concept of the quadratic function and the area of a flat shape.

The next stage is organizing which can be seen in Figure 2. At this stage, S1 looks for the area of several triangles in the shaded area. S1 states that the shaded area is a combination of 4 triangles. Then S1 seeks the length of $\mathrm{Bb}$ with the concept of similarity.Thus, at the organizing stage, S1 can describe the strategies by using the obtained initial information, namely by finding the shaded area of a triangle and the quadratic function.

After doing the organizing stage, the next step is attributing. At this stage, $\mathrm{S} 1$ writes to find the minimum area, it must find the value of $\mathrm{x} \_$min $=$ $(-\mathrm{b}) / 2 \mathrm{a}$. This is consistent with the concept of the quadratic function. S1 can relate problems that are equipped with information or knowledge to solve problems such as relating to the concept of the triangle area of $L=\frac{1}{2}$. a.t and the concept of similarity to find the length of $B b$. Regarding this case, can rebuild a new scheme to solve the problem, so that he/she can solve it according to the objectives of the presented problems.

\section{Subject 2 (S2) has medium mathematics ability}

The following describes the analytical thinking process of $\mathrm{S} 2$ in solving the quadratic function material problem. In the differentiating stage, S2 does not write down the known information in detail, but S2 implicitly explains it through Figure 3. Then the researchers conduct an interview to obtain further information about the differentiating process. The results of the interview show that $\mathrm{S} 2$ can collect important information, such as the known and the asked information in verbal questions. Then S2 mentions alternative solutions, namely by using the area of the plane, congruence, and quadratic functions.

The next stage is organizing which can be seen in Figure 3. At this stage, S2 looks for the area of the rhombus. Then S2 finds the area of the rectangle by finding the length $\mathrm{Pa}$ using the concept of similarity. S2 states that the shaded area is the area of the rhombus minus the rectangular area. In this case, S2 can organize the information obtained to solve problems and describe the used strategies, but there are errors in the process of calculations.

Then, S2 does the attributing stage. At this stage, S2 seeks the minimum area, namely by finding the difference between the area of a rhombus and a rectangle. S2 links the problem which is equipped with information or knowledge to solve the problem but has not been able to solve it based on the objectives of the presented problems. 
DOI: https://doi.org/10.24127/ajpm.v10i1.3440

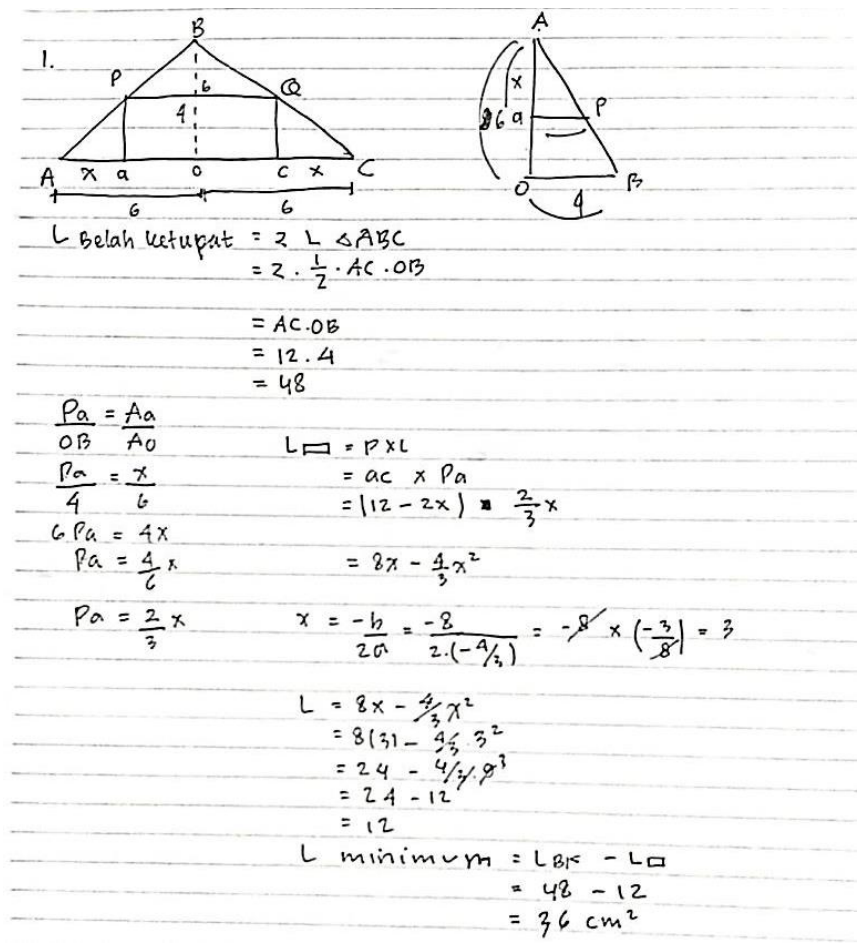

Figure 3. The answer of subject 2 (S2)

\section{Subject 3 (S3) has low mathematical ability}

The answer of S3 in the differentiating stage can be seen in Figure 4. S3 writes the known information, but he/she does not write down the asked information. Based on the interview results of $S 3$, the shaded area is equal to the two area of the small triangles plus the two large triangle. S3 also states that the questions are so difficult. Based on the answer sheets and interviews, it reveals that S3 has not been fully able to sort and collect important information, such as the known and the asked information of the questions, both in writing and orally.

The next stage is organizing which can be seen in Figure 4. At this stage, S3 looks for the area of the small triangle and the area of the large triangle. However, there is a mistake in writing a small triangle $=a . t$. This is not compatible with the concept of finding the triangle area. Furthermore, the researchers conduct interviews to obtain further information about the organizing process. At the organizing stage, S3 has not been able to describe the used strategy. S3 finds difficulty in doing the task. So that, at this stage, S3 does not describe the solution completely and does not get the right answer.

After doing the organizing stage, the next step is attributing. At this stage, S3 looks for the shaded area, namely $(2 \times$ bo. $x)((12-2 x) B b$. This is not in line with the initial concept. At the beginning, S3 states that the area of the shape is shaded by adding 2 small triangular areas and 2 large triangle areas. At this stage, S3 uses the multiplication operation in doing it. The results of the interview explain that at the attributing stage, S3 does not mention the right answer. Based on that, it can be concluded that S3 has not been able to solve problems based on $=$ the objectives of the presented problems. 
DOI: https://doi.org/10.24127/ajpm.v10i1.3440

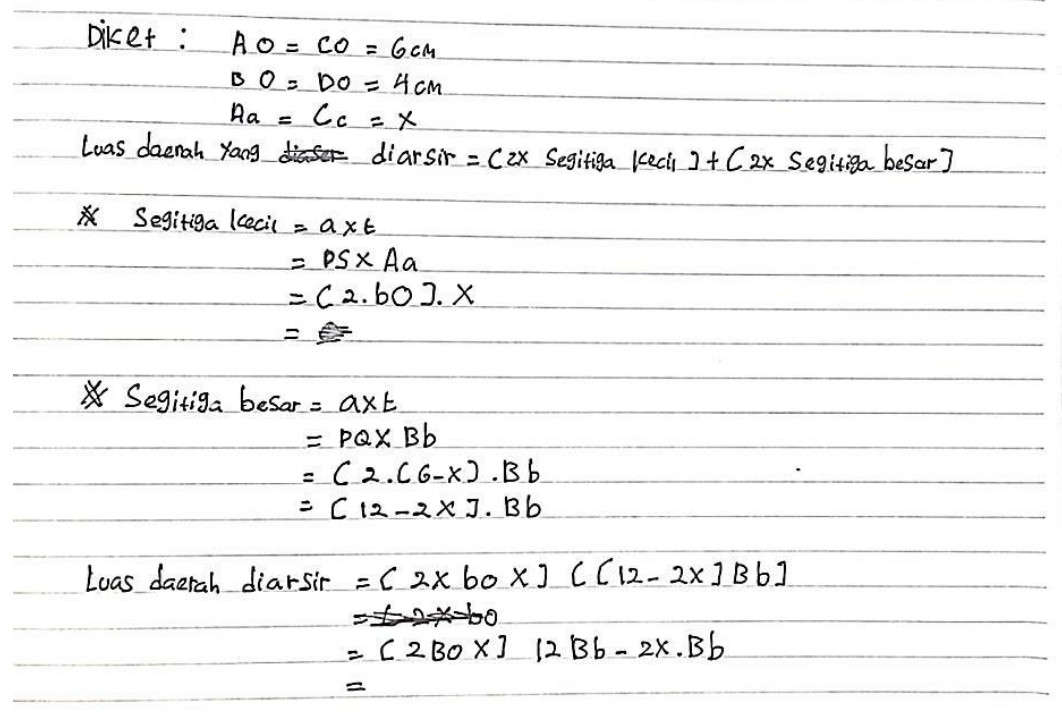

Figure 4. The answer of subject 3 (S3)

Table 2. The analysis results of students' answer

\begin{tabular}{cccc}
\hline \multirow{2}{*}{ Subject } & \multicolumn{3}{c}{ Analytical thinking Stage } \\
\cline { 2 - 4 } & Differentiating & Organizing & Attributing \\
\hline S1 & $\checkmark$ & $\checkmark$ & $\checkmark$ \\
S2 & $\checkmark$ & $\checkmark$ & - \\
S3 & - & - & - \\
\hline
\end{tabular}

Based on Table 2, the results of the students' worksheet, and the results of students' interviews that have been analyzed, the analytical thinking stages of the subject with high mathematics abilities can be achieved well. S1 can describe the presented problems and the solution, and answer correctly. The process of analyzing and deciphering problems is a stage in analytical thinking. This is in line with (Sitthipon, 2012) which states that analytical thinking is the competence in identifying or classifying various aspects in the form of objects, stories or events, as well as the ability to find the relationship of these aspects. In addition research conducted by (Setiawati et al., 2020) which states that highly skilled students can answer problems using words or written text with the result of solving the questions mostly correct. Based on the interview, it is known that S1 can link the problems that are equipped with information or knowledge to solve problems. This result is in line with research (Utami et al., 2020) which states that highcategory students can correctly connect new knowledge with previous understanding and can find relationships and formulate solutions.

Meanwhile, the student with medium mathematics ability is not fully able to describe the solutions and strategies to solve the problems. This is in line with the research of Retna and Mubarokah (2013) which explains that student with medium ability is less able to state the steps in solving problems using concepts that have been studied, 
and is less able to improve the mistaken answer.

The student with low mathematics ability is less able to link their initial knowledge to solve problems. This occurs because S3 does not understand the meaning of the problem or an error occurs in it. It is in accordance with the research conducted by Jha (2012), the error in understanding the questions is caused by the students' incomplete understanding of the questions so that S3 does not write down the known information of the questions. Based on the interviews conducted, S3 experiences confusion and difficulty in understanding the questions. This indicated that S3 can't solve the quadratic function problem solving problems. This is in line with previous research conducted by Rizki and Wildaniati (2015) which states that the students experience confusion in applying the quadratic function formula to solve the problems. The students who have low initial mathematics ability have difficulty in connecting the obtained information to develop strategies (Lutfiananda et al., 2016).

Based on the results of the discussion above, there is an interesting thing to discuss, namely giving problem to the subject can stimulate students' analytical thinking. By increasingly familiarizing students with problem solving, it can improve their analytical thinking process. Based on the description of the subject's analytical thinking process, it can be employed as one of the bases so that the teacher trains and engages students with problem solving more often in the subsequent lesson. In addition, this research will be very useful to train students' analytical thinking processes to understand the questions given more thoroughly, and to solve questions related to quadratic functions and they will have an impact on students' academic achievement. Thus the results of this study are expected to provide a positive contribution to the world of education, especially mathematics learning.

\section{CONCLUSION AND SUGGESTION}

Based on the results of data analysis and discussion, it can be concluded that the student who has high mathematics abilities can pass through the three stages of analytical thinking, namely differentiating, organizing, and attributing in solving math problems with quadratic functions. Whereas, the student who has medium ability can pass two analytical thinking stages, namely differentiating and organizing in solving math problems with quadratic functions. However, at the attributing stage, the student is less able to complete the answer based on the objectives of the presented problems. The student with low mathematics ability category tends to not to conduct the differentiating, organizing, and attributing analytical thinking stages in solving math problems with quadratic functions. The student is less able to solve quadratic function problems according to the problem-solving steps.

The results of the research can be utilized as a theoretical study to determine the analytical thinking process in solving mathematical problems related to quadratic functions. In addition, the results of this study are expected to be used by teachers as additional information to find more effective and efficient teaching methods.

The researchers suggest for other research to develop this analytical thinking process in terms of various 
aspects. For example, by reviewing cognitive style, IQ, gender differences or others. Further research can be carried out for students in other schools related to the students' analytical thinking processes in solving mathematics problems on another focus, for example on math topics other than quadratic functions. Meanwhile, the teachers must pay more attention to the students' analytical thinking processes, so that each student can develop their potentiality. The teachers need to increase the variety of mathematics problems material which being taught so that the students' problem-solving skills can develop.

\section{REFERENCES}

Anderson, L. W., David R Krathwohl, Airasian, P. W., Cruikshank, K. A., Mayer, R. W., Pintrich, P. R., Raths, J., \& Wittrock, M. C. (2001). A Taxonomy for Learning, Teaching and Assessing (A Revision of Bloom's Taxonomy of Educational Objectives). Longman.

Ayunengdyah, N., Khabibah, S., \& Saraswati, S. (2020). Analisis Kesalahan dalam Memecahkan Masalah Fungsi Kuadrat Berdasarkan Langkah Polya. Jurnal Pendidikan Matematika, 1(2), 120-128.

Chadwick, D. C. (2016). Enhancing Student Critical and Analytical Thinking Skills at A Higher Education Level in Developing Countries: Case Study of The British University in Dubai. Journal of Educational and Instructional Studies in The World, 6(1), 67-77.

Gurat, M. G. (2018). Mathematical Problem-Solving Strategies among Student Teachers. ERIES Journal, 11(3), 53-64.

Ilma, R., Hamdani, A. S., \& Lailiyah, S. (2017). Profil Berpikir Analitis Masalah Aljabar Siswa Ditinjau dari Gaya Kognitif Visualizer dan Verbalizer. Jurnal Review Pembelajaran Matematika, 2(1), 1-14. https://doi.org/10.15642/ jrpm.2017.2.1.1-14

Isfan, I., Rahim, U., \& Jazuli, L. O. A. (2019). Analisis Kesalahan dalam Menyelesaikan Soal-Soal Fungsi Kuadrat pada Siswa Kelas X-3 SMA Negeri 1 Asera. Jurnal Penelitian Pendidikan Matematika, 6(1), 43-56. https://doi.org/10.36709/jppm.v $6 \mathrm{i} 1.7393$

Jha, S. K. (2012). Mathematics Performance of Primary School Students in Assam (India): An Analysis Using Newman Procedure. International Journal of Computer Applications in Engineering Sciences, II(1), 1721.

Lutfiananda, I. M. A., Mardiyana, \& Saputro, D. R. S. (2016). Analisis Proses Berpikir Reflektif Siswa dalam Memecahkan Masalah Matematika Non Rutin di Kelas VIII SMP Islamic International School Pesantren Sabilil Muttaqien (IIS PSM) Magetan Ditinjau dari Kemampuan Awal. Jurnal Elektronik Pembelajaran Matematika, 4, 812-823.

Miles, M. B., Huberman, A. M., \& Saldaña, J. (2014). Qualitative data analysis: A methods sourcebook (Third edition). SAGE Publications, Inc.

Montaku, S. (2011). Results of Analytical Thinking Skills Training through Students in System Analysis and Design 
DOI: https://doi.org/10.24127/ajpm.v10i1.3440

Course. Proceedings of the IETEC'11 Conference.

Parta, N. (2016). Karakteristik Berpikir Analitis Mahasiswa dalam Menyelesaikan "Masalah Sederhana." Seminar Nasional Pendidikan Matematika Pascasarjana UM. https://doi.org/10.13140/RG.2.1.4 728.2167

Qolfathiriyus, A., Sujadi, I., \& Indriati, D. (2019a). Characteristic profile of analytical thinking in mathematics problem solving. Journal of Physics: Conference Series, 1157, 032123.

https://doi.org/10.1088/17426596/1157/3/032123

Qolfathiriyus, A., Sujadi, I., \& Indriati, D. (2019b). Students' Analytical Thinking Profile Based on Reflective Cognitive Style in Solving Mathematics Problem. Journal of Physics: Conference Series, $\quad 1306, \quad 012016$. https://doi.org/10.1088/17426596/1306/1/012016

Retna, M., Mubarokah, L., \& Suhartatik. (2013). Proses Berpikir Siswa dalam Menyelesaikan Soal Cerita Ditinjau Berdasarkan Kemampuan Matematika. Jurnal Pendidikan Matematika STKIP PGRI Sidoarjo, 1(2), 71-82.

Rizki, S., \& Wildaniati, Y. (2015). Efektifitas Bahan Ajar dan Media Berbasis ICT pada Materi Persamaan dan Fungsi Kuadrat. AKSIOMA: Jurnal Program Studi Pendidikan Matematika, 4(2), 18.

https://doi.org/10.24127/ajpm.v4i 2.292

Robbins, J. K. (2011). Problem solving, reasoning, and analytical thinking in a classroom environment. The Behavior Analyst Today, 12(1), 41-48.

https://doi.org/10.1037/h0100710
Setiawati, F. N., Widadah, S., \& Agustina, E. N. S. (2020). Representasi Matematis Siswa SMP Berkemampuan Tinggi dalam Menyelesaikan Soal Matematika. Indonesian Journal of Mathematics and Natural Sciences Education, 1(2), 111120.

Sitthipon, A.-I. (2012). Development of Teachers' Learning Management Emphasizing on Analytical Thinking in Thailand. Procedia Social and Behavioral Sciences, 46 ,

https://doi.org/10.1016/ j.sbspro.2012.06.063

Sutiarso, S. (2017). Meningkatkan Kemampuan Komunikasi dan Pemecahan Masalah dalam Pembelajaran Matematika. Prosiding Seminar Nasional Matematika dan Pendidikan Matematika 2017 UIN Raden Intan Lampung, 289-295.

Thaneerananon, T., Triampo, W., \& Nokkaew, A. (2016). Development of a Test to Evaluate Students' Analytical Thinking Based on Fact versus Opinion Differentiation. International Journal of Instruction, 9(2), 123-138. https://doi.org/10.12973/iji.2016.9 $29 \mathrm{a}$

Utami, W. P., Angkotasan, N., \& Suratno, J. (2020). Kemampuan Berpikir Reflektif Matematis Siswa dalam Menyelesaikan Soal Program Linear. Delta-Pi: Jurnal Matematika dan Pendidikan Matematika, 9(1), 34-43 